\title{
Geographical Distribution, Habitat and Reproductive Phenology of the Genus Kallymenia (Gigartinales, Rhodophyta) from Catalonia, Spain
}

\author{
C. Rodríguez-Prieto* and A. Vergés \\ University of Girona, Campus de Montilivi s/n, 17071 Girona, Spain \\ * Corresponding author
}

The authors report the geographical distribution, habitat and reproductive phenology of the four species of the genus Kallymenia from Catalonia, Spain: K. feldmannii Codomier, K. lacerata J. Feldmann, K. patens (J. Agardh) Parkinson and K. requienii J. Agardh. The records confirm that these species are quite common in the western Mediterranean Sea, but are very rare in the eastern Mediterranean region, where only $K$. lacerata and $K$. requienii have been found once. In addition, the examination of different herbaria shows that K. requienii is present on the Atlantic coast of the north of Spain. The four species are sciophilous and live preferably in the coralligen or in the maerl, usually at depths of more than $30 \mathrm{~m}$ in the northern Mediterranean Sea or below $40 \mathrm{~m}$ in the central and southern Mediterranean Sea. All species are highly proterandrous. Kallymenia feldmannii and $K$. lacerata are annual and ensure survival in winter by developing incrusting discs from carpospores and tetraspores. Kallymenia patens and $K$. requienii are perennial, and ensure survival by maintaining only the basal part of the blade from one year to the other and developing new blades from it in spring. The perennial species, on aging, accumulate floridean starch in the intermediate cortical layers, which takes the form of whitish spots on the blade surface; the older thalli are totally whitish.

\section{Introduction}

The genus Kallymenia J. Agardh (Kallymeniaceae, Gigartinales, Rhodophyta) is composed of foliaceous species of multiaxial construction. All of them are characterized by having: (a) an essentially filamentous medulla, but with several lightly staining stellate or ganglionic cells remaining, (b) a cortex composed of layers of cells not arranged in distinct anticlinal filaments and diminishing in size towards the outside: the innermost cells are stellate and lie in the plane of flattening, (c) a triphasic life history with isomorphic gametophytes and tetrasporophytes, (d) a non-procarpic female reproductive structure, (e) a carpogonial branch system usually with a lobed supporting cell that gives rise to several sterile lobed (subsidiary) cells, and with one or more 2-celled carpogonial branches arising from the subsidiary cell, and (f) tetrasporangia scattered over the whole thallus, in the outer cortex. The contents of the tetrasporangia are cruciately or irregularly divided. The genus Kallymenia is well represented on the northwestern Mediterranean coasts of Spain, where 4 species are reported: K. feldmannii Codomier, K. lacerata J. Feldmann, $K$. patens (J. Agardh) Parkinson and $K$. requienii J. Agardh. Much has been said about the geographic distribution of these species and their possible presence on the Atlantic coast of Spain and France and in the Canary Islands, but hitherto no light has been shed on this. No data about their phenological behavior is available either.
In this work we report on: a) the geographic distribution of the four species of the genus Kallymenia, b) their habitat, and c) the most characteristic features of their phenological behavior.

\section{Materials and Methods}

This study was conducted on the basis of the examination of individuals present in the Phycological Herbaria of different Universities of Spain and from floristic surveys of subtidal algal communities made between January 1996 and September 1999 at many points on the coast of the Iberian Peninsula, Balearic Islands and France. Collections were made by SCUBA diving always on sublittoral bottoms at depths of between 10 and $50 \mathrm{~m}$. The species were found only in pristine areas. The sampling was carried out all the year round to allow the observation of the phenology of the different species, but due to their strong seasonality, sampling was intensified in spring and summer. Specimens were deposited in the Phycological Herbarium of the University of Girona, Spain (HGI-A). The other herbaria examined are those of the Universities of Santiago de Compostela (SANT), Barcelona (BCF), Complutense de Madrid (MAF), La Laguna (TFC), Las Palmas de Gran Canaria (BCM), Málaga (MGC) and Valencia (VAB).

The different species of Kallymenia were determined to species level and the reproductive status of each one was reported (sterile, male gametophyte, fe- 
male gametophyte including carposporophyte and tetrasporophyte).

\section{Results}

\section{Kallymenia feldmannii Codomier}

Kallymenia feldmannii Codomier 1971: 36, figs 20-24; Codomier 1972: fig. 30 (e-f), fig. 46 (e-r, $\mathrm{w}-\mathrm{z}$ ), fig. 52, fig. 53 bis, fig. $54(\mathrm{a}-\mathrm{c})$, fig. $55(\mathrm{a}-\mathrm{b})$, figs 56-62, Vergés 2000: 21-35, figs 2-12.

Geographical distribution: Kallymenia feldmannii has been collected only from the western Mediterranean Sea (Table I, Fig. 1). It has been found on the northern coast of Spain (Ballesteros i Sagarra 1980) and in the Balearic Islands (Ballesteros 1992a, 1993). In France it is known from Banyuls de la Marenda (Codomier 1968, 1971, Knoepffler et al. 1990), Marseilles (Huvé and Passelaigue 1970), and Corsica (Coppejans 1979, 1982, Verlaque 1987). In Italy it has been collected from the Tuscany archipelagos (Papi et al. 1992), from several places in Sicily and the Strait of Messina (Codomier and Giaccone 1972, Giaccone and Rizzi-Longo 1976, Furnari et al. 1977, Cormaci et al. 1978, 1985, Giaccone and Di Martino 1996, Marino et al. 1998) and from the Sicily channel (Giaccone et al. 1972). Finally, Codomier and Giaccone (1972) reported this species had been found by J. Feldmann in Algeria. After a bibliographic revision of the J. Feldmann publications, no citations of $K$. feldmannii were found for Algeria, and we think that the report of Codomier and Giaccone (1972) is due to a confusion with $K$. lacerata, a species described on the basis of a specimen from Algeria.

In this work we report on some new localities from the northeast of Spain, from the Balearic Islands and from the Alboran Sea (Table I, Fig. 1). The specimen from the Alboran Sea is in the Herbarium of the University of Málaga (MGC 3336 Phyc) and was misidentified as $K$. requienii.

Habitat: Kallymenia feldmannii grows in the coralligen [organic concretion consisting basically of the incrusted red algae Mesophyllum alternans (Foslie) Cabioch et Mendoza and Lithophyllum frondosum (Dufour) Furnari, Cormaci et Alongi], and in maerl. It is present usually at depths of more than $30 \mathrm{~m}$; the maximum depth at which it has been found being $93 \mathrm{~m}$, at Cabrera, Balearic Islands (Ballesteros 1993). Nevertheless, some individuals have been found living at shallower depths, i. e. the individuals HGI-A 4035, 4064 and 4065, were found at a depth of $10 \mathrm{~m}$ at the entrance to the Cova Blava cave (Cabrera, Balearic Islands), and the individual collected by Codomier and Giaccone (1972) at the Esc. dels Ciclopi (Catania, Italy) was from a depth of only $1 \mathrm{~m}$. Associated species in its habitat include different species of Peyssonnelia, other Kallymenia spp. (K. lacerata and $K$. requienii) and Contarinia squamariae (Meneghini) Denizot.
Phenology: This species has been collected mainly in spring and summer. The first individuals appear in March-April, and the last before the autumn storms. Records for later in the year (i. e. in December) seem to be exceptional. The young individuals (from AprilMay) were usually sterile or male gametophytes, whereas in adult individuals the female structures were increasingly more common (Table II).

\section{Kallymenia lacerata J. Feldmann}

Kallymenia lacerata Feldmann 1942: 10, fig. 2; Huvé and Passelaigue 1970: 47, pl. 2 (b); Codomier 1971: 44, figs 25-28; Cinelli and Codomier 1974: fig. 1 (a); Athanasiadis 1987: 46; Vergés 2000: 61-73, figs $13-21$.

Geographical distribution: Kallymenia lacerata is known mainly from the western Mediterranean Sea but has also been reported from Sithonia, Greece, in the eastern Mediterranean Sea (Athanasiadis 1987) (Table I, Fig. 1). In Spain, references to it are rare and it has been only found on the northern coast (Ballesteros i Sagarra 1983, 1984) and in the Balearic Islands (Ballesteros et al. 1997). In France it is known from Banyuls de la Marenda (Codomier 1968, 1971, Cinelli and Codomier 1974, Knoepffler et al. 1990), Marseilles (Huvé and Passelaigue 1970), Port-Cros (Belsher et al. 1976) and Corsica (Coppejans 1979, 1982, Verlaque 1990, Rodríguez-Prieto et al. 1993). In Italy it is known from Naples (Cinelli and Codomier 1974) and from Sicily and the Strait of Messina (Codomier and Giaccone 1972, Giaccone and Rizzi-Longo 1976, Furnari et al. 1977, Cormaci et al. 1985, Marino et al. 1998). Finally, it is also known from Algeria, where J. Feldmann collected the type in 1938 at Borj-el-Bahri (Feldmann 1942). Since then, there have been no further citations from this country.

In this work we give some new records from the northeast of Spain, the Balearic Islands and the Columbrets Islands (Table I, Fig. 1).

Habitat: Kallymenia lacerata appears to be common in the coralligen or even in maerl, usually at depths of more than $30 \mathrm{~m}$ in the northwestern Mediterranean Sea and at more than $40 \mathrm{~m}$ in the central and southern Mediterranean Sea. The greatest depth at which it has been found is $71 \mathrm{~m}$ (Ballesteros et al. 1997). Nevertheless, it can also develop at shallower depths, in dark places. The shallowest depth at which it has been found is $10 \mathrm{~m}$ (HGI-A 4000, entrance to the Cova Blava cave, Cabrera, Balearic Islands). Associated species in its habitat are the same as for $K$. feldmannii.

Phenology: This species has been collected from spring until early autumn and once in December. The first individuals appear in April and, while we found one individual in December, usually the latest appear before the autumn storms. The young individuals 
Table I. Geographical distribution of the different species of Kallymenia studied grouped by localities. Data, number of individuals and reproductive status of each one (in square brackets) and collector and/or bibliographical reference are indicated. The number indicated before each locality corresponds to the geographical distribution shown in Figure 1.

\begin{tabular}{|c|c|c|c|c|c|c|c|c|}
\hline Localities & & Illymenia feldmannii & & llymenia lacerata & & llymenia patens & & Ilymenia requienii \\
\hline Cap de Creus (E) & & & & & & 20-6-1996 [1 s], CRP & 1 & 14-7-1998 [2 s], CRP and AV \\
\hline $\begin{array}{l}\text { L'Estartit and } \\
\text { Medes I. (E) }\end{array}$ & 1 & $\begin{array}{l}\text { 18-6-1998 [2 s], } \\
\text { CRP and AV } \\
10-7-1998[1 \mathrm{~s}], \\
\text { CRP and AV } \\
10-8-1998[3 \mathrm{~s}] \\
\text { CRP and AV }\end{array}$ & 1 & $\begin{array}{r}26-6-1998[1 \mathrm{~s}] \\
\text { CRP and AV }\end{array}$ & 2 & $\begin{array}{r}10-7-1998[1 \mathrm{~s}] \\
\text { CRP and AV }\end{array}$ & 2 & $\begin{array}{l}\text { Ballesteros i Sagarra and Romero Martinengo } 1982 \\
\text { Ballesteros et al. } 1984 \\
\text { 14-8-1989, Verlaque } 1990 \\
\text { June } 1998 \text { [2 s, } 2 \text { f, } 2 \text { t], CRP and AV } \\
\text { 10-7-1998 [3 s], CRP and AV }\end{array}$ \\
\hline Begur (E) & & & & & 3 & 3-8-1999 [1 s], CRP & 3 & $\begin{array}{l}\text { 5-6-1998 [1 s], CRP and AV } \\
\text { 3-8-1998 [1 s], CRP } \\
\text { 24-5-1999 [1 f], L Lavelli, BCF } 12306\end{array}$ \\
\hline $\begin{array}{l}\text { Els Ullastres, } \\
\text { Llafranc (E) }\end{array}$ & & & 2 & 25-7-1999 [1 m], CRP & & & & \\
\hline $\begin{array}{l}\text { Formigues I., } \\
\text { Món del Padró, } \\
\text { La Llosa and } \\
\text { Món de Fora, } \\
\text { Palamós (E) }\end{array}$ & 2 & $\begin{array}{l}\text { 8-6-1997 [1 s], May } 1998 \\
\text { [6 s], 28-6-1998 [2 s, } 1 \mathrm{f}] \text {, } \\
\text { 30-8-1998 [4 s, } 4 \mathrm{f}, 2 \mathrm{ft}] \text {, } \\
\text { CRP } \\
\text { 6-12-1998, [1 mt], CRP } \\
\text { April 1999 [4 s, 1 m], CRP } \\
\text { 23-5-1999 [1 s], CRP }\end{array}$ & 3 & $\begin{array}{l}\text { 6-12-1998, [1 f], CRP } \\
\text { April } 1999 \text { [2 s], CRP } \\
\text { 24-5-1999 [1 s], CRP } \\
\text { 1-8-1999 [2 s, } 1 \mathrm{mf}], \text { CRP } \\
\text { 30-8-1998 [6 s], CRP }\end{array}$ & 4 & $\begin{array}{l}\text { 17-5-1998 [1 s], CRP } \\
\text { June } 1999 \text { [5 s, } 1 \text { t], CRP }\end{array}$ & 4 & $\begin{array}{l}\text { May } 1997 \text { [2 s, } 1 \text { t], CRP } \\
\text { 8-6-1997 [2 s], CRP } \\
\text { May } 1998 \text { [2 s], CRP } \\
\text { June } 1998 \text { [6 s], CRP } \\
\text { 6-12-1998 [1 s, 1 t], CRP } \\
\text { 28-3-1999 [1 s], CRP } \\
\text { April } 1999 \text { [6 s, } 1 \mathrm{~m}, 1 \mathrm{t}], \text { CRP } \\
\text { May } 1999 \text { [2 s], CRP }\end{array}$ \\
\hline Tossa de Mar (E) & 3 & Ballesteros i Sagarra 1980 & 4 & $\begin{array}{l}\text { [1 s], Ballesteros i } \\
\text { Sagarra } 1983 \\
\text { 4-10-1983, Ballesteros i } \\
\text { Sagarra } 1984\end{array}$ & 5 & $\begin{array}{l}\text { 30-7-1983 [1 s], Ballesteros } \\
\text { i Sagarra } 1984\end{array}$ & 5 & $\begin{array}{l}\text { Ballesteros i Sagarra } 1983 \\
\text { 17-10-1982, 14-7-1983, September } 1983 \text { [2], October } 1983 \text { [3], } \\
\text { Ballesteros i Sagarra } 1984\end{array}$ \\
\hline $\begin{array}{l}\text { Mallorca, Balearic I. } \\
\text { (E) }\end{array}$ & 4 & $\begin{array}{l}\text { 18-5-1991 [2 s], Ballesteros } \\
\text { 1992a }\end{array}$ & & & & & 6 & 23-6-1987, Ballesteros 1992b \\
\hline $\begin{array}{l}\text { Minorca, Balearic I. } \\
\text { (E) }\end{array}$ & 5 & $\begin{array}{c}\text { 28-7-1994 [1 s] } \\
\text { EB and NS }\end{array}$ & 5 & $\begin{array}{l}\text { 22-7-1994 [1 s], } \\
\text { Ballesteros et al. } 1997 \\
\text { 28-7-1994 [1 s], } \\
\text { EB and NS }\end{array}$ & 6 & $\begin{array}{l}\text { 28-11-1887, 7-7-1888, Rodríguez } \\
\text { y Femenías } 1889 \\
\text { [7], Rodríguez y Femenías } 1889 \\
\text { 18-8-1887, 5-6-1888, 8-11-1890, } \\
\text { Seoane-Camba 1969 } \\
\text { 3-9-1887, Codomier } 1971 \\
\text { Codomier } 1972 \\
\text { 28-12-1994 [1 s], EB and NS }\end{array}$ & 7 & $\begin{array}{l}\text { 3-9-1887, 21-6-1888, 22-9-1889, 18-6-1888, 20-7-1888, 5-10-1888, 11-10-1895, } \\
\text { 14-10-1895, Seoane-Camba 1969 } \\
11-10-1895 \text { [1 f], Codomier 1971 } \\
\text { 27-6-1986, 28-6-1986, 2-7-1986, Ballesteros } 1994 \\
28-7-1994 \text { [3 s], EB and NS } \\
26-7-1996 \text { [3 s], CRP } \\
25-5-1997 \text { [2 s], CRP } \\
\text { 25-6-1997 [6 s, 1 f], CRP } \\
26-7-1996 \text { [1 s], CRP }\end{array}$ \\
\hline $\begin{array}{l}\text { Cabrera, Balearic I. } \\
\text { (E) }\end{array}$ & 6 & $\begin{array}{l}\text { Ballesteros } 1993 \\
\text { May } 1996[5 \text { s], CRP } \\
11-6-1996 \text { [1 t], NS }\end{array}$ & 6 & May 1996 [12 s], CRP & & & 8 & $\begin{array}{l}\text { 18-10-1986, Ballesteros 1992b } \\
\text { [2], Ballesteros } 1993 \\
\text { 12-5-1985, June } 1996 \text { [2], July 1986, Ballesteros } 1994 \\
\text { May } 1996 \text { [8 s, } 1 \text { f], CRP }\end{array}$ \\
\hline
\end{tabular}




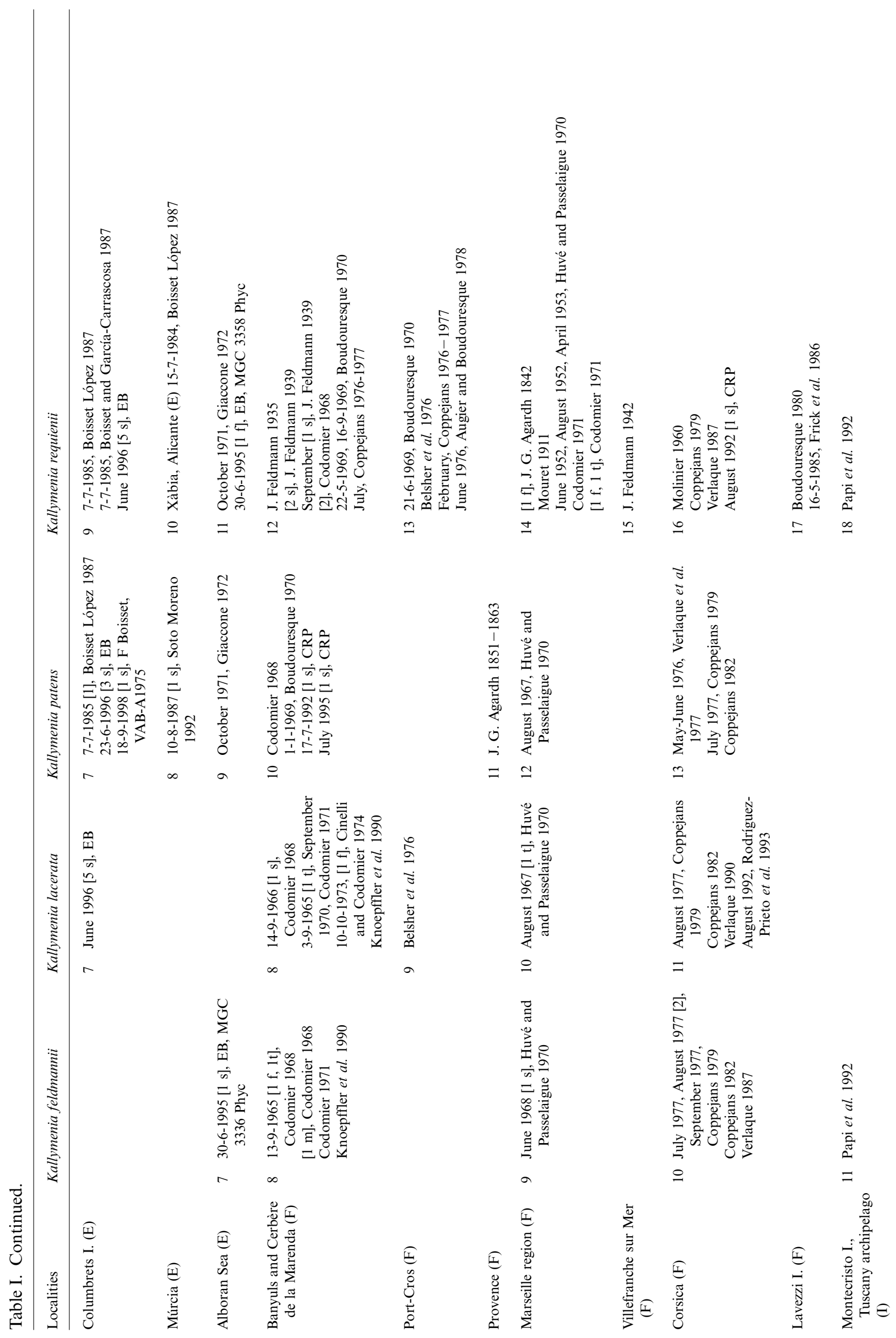


Naples region (I)

Sardinia (I)

Sicily and Strait of Messina (I)

12 August 1968, May 1969 mier and Giaccone 1972

Giaccone and Rizzi-Longo 1976

Furnari et al. 1977

[2], Cormaci et al. 1978

1-3-1980, Cormaci et al.

1985

Giaccone and Di Martino

1996

May 1996, Marino et al. 1998

Sicily channel (I)

13 24-9-1971, Giaccone et al.

1972
12 29-9-1972 [1 f]. Cinelli and Codomier 1974

3 August 1970, Codomier and Giaccone 1972 Giaccone and Rizzi-Longo 1976 Furnari et al. 1977 Cormaci et al. 1985 May 1996, October 1996 , Marino et al. 1998

16

Tabarka (TUN)

Bordj-El-Bahri (Alg)

14 20-10-1938 [1 f],

J. Feldmann 1942

15 Athanasiadis 1987

Sithonia (Gr)
14 July 1970 [1 s], Feoli and Bressan 19 [1 t], Cinelli and Codomier 1974

15 Brambati et al. 1980

20 Brambati et al. 1980

6 Mazza 1904

January 1966, July 1968, $\quad 21$ Lagenbach 1873

Codomier Ardissone 1883

[3], Mazza 1904

Gist 1970, April 1971,

Codomier 1969

Furnari and Scammacca 1973

Giaccone and Rizzi-Longo 1976

Furnari et al. 1977

Cormaci and Furnari 1979

Battiato et al. 1980

Spring and Autumn 1983,

Giaccone et al. 1985

October 1996, Marino et al. 1998

17 September 1971 [2], Giaccon et al. 1972

Giaccone et al. 1973

May 1972, Giaccone an

May 1972, Giacco
Sortino 1974

[1 f], Cinelli et al. 1976

August 1970, April 1971, Giaccone 1972

Furnari et al. 1977

Cormaci and Furnari 1979

Battiato et al. 1980

22 September, Codomier and Giaccone 1972

September 1971 [2], Giaccone et

Giaccone et al. 1973

[1 f], Cinelli et al. 1976

May, August 1970, Codomier and Giaccone 1972

April-May [2 m, 2 f], Furnari and Scammacca 1973

23-1-1980, 28-2-1980, 28-3-1980, 13-9-1982, Cormaci et al. 1985

Spring and Autumn 1983, Giaccone et al. 1985

May 1972, June 1972, Giaccone and Sortino 1974

23 24-4-1969, Boudouresque 1970

24 Alger (ALG) [1 f], Montagne 1846

17-5-1939 [1 f], J. Feldmann 1942

Akkuyu, Messin (TUR)

25 Cirik 1991

26 5-10-1994, BCF 10568

Xové, Lugo (E)

Malpica and Punta

Aruela, A Coruña (E)

Cangas, Pontevedra (E)

27 8-9-1994 [1 f, 1 t], J. Cremades and I. Bárbara, SANT 616

18-8-93 [1 f]. J. Cremades, I. Bárbara and A. Granja, SANT 6164

8-9-1994 [1 s], J. Cremades, I. Bárbara, A. Granja and A. J. Veiga, SANT 6164 8-9-1994 [1 f], J. Cremades, I. Bárbara, A. Granja and A. J. Veiga, SANT 6190

28 27-3-1994 [1 f], J. Cremades, I. Bárbara, A. Granja and A. J. Veiga, SANT 6464 27-3-1994 [1 f], J. Cremades, I. Bárbara, A. Granja and A. J. Veiga, SANT 6465 27-3-1994 [1 f], J. Cremades, I. Bárbara, A. Granja and A. J. Veiga, SANT 6466 28-2-1998 [1 s], J. Cremades, SANT 9674

29 15-4-97 [3 f, 1 t], I. Bárbara, A. Granja and A. J. Veiga, SANT 5602

Abbreviations: $\mathrm{f}=$ female gametophyte; $\mathrm{ft}=$ female gametophyte and tetrasporophyte at the same time; $\mathrm{m}=$ male gametophyte; $\mathrm{mf}=\mathrm{male}$ and female gametophyte at the same time; $\mathrm{mt}=$ male gametophyte and tetrasporophyte at the same time; $\mathrm{s}=$ sterile; $\mathrm{t}=$ tetrasporophyte; $\mathrm{AV}=\mathrm{A}$. Vergés; $\mathrm{CRP}=\mathrm{C}$. Rodríguez-Prieto; $\mathrm{EB}=\mathrm{E}$. Ballesteros; $\mathrm{NS}=\mathrm{N}$. Sant. 
(from April to June) were usually sterile or male gametophytes and adults frequently bear female reproductive structures (Table II).

\section{Kallymenia patens (J. G. Agardh) Parkinson}

Halymenia patens J. G. Agardh 1851-1863: 203; Kützing 1866: pl. 94.

Halarachnion patens (J. G. Agardh) De Toni 1905: 1654; Preda 1908-1909: 65.

Kallymenia patens (J. G. Agardh) Codomier 1971: 27, figs 15-17; Huvé and Passelaigue 1970: 47, pl. 1 b.
Kallymenia patens (J. G. Agardh) Parkinson 1980: 16; Vergés 2000: 95-106, figs 22-28.

Geographical distribution: Kallymenia patens is known only from the western Mediterranean Sea (Table I, Fig. 2). In Spain it is widespread: it has been collected on the northeastern coast (Ballesteros i Sagarra 1984), in the Balearic Islands, where it was found several times in Minorca at the end of the 19th century by J. J. Rodríguez y Femenías (Rodríguez y Femenías 1889, Seoane-Camba 1969, Codomier 1971, 1972), in the Columbrets Islands (Boisset López 1987), in Murcia, (Soto Moreno 1992) and in the Alboran Sea (Giaccone 1972). In France it has been found at Banyuls
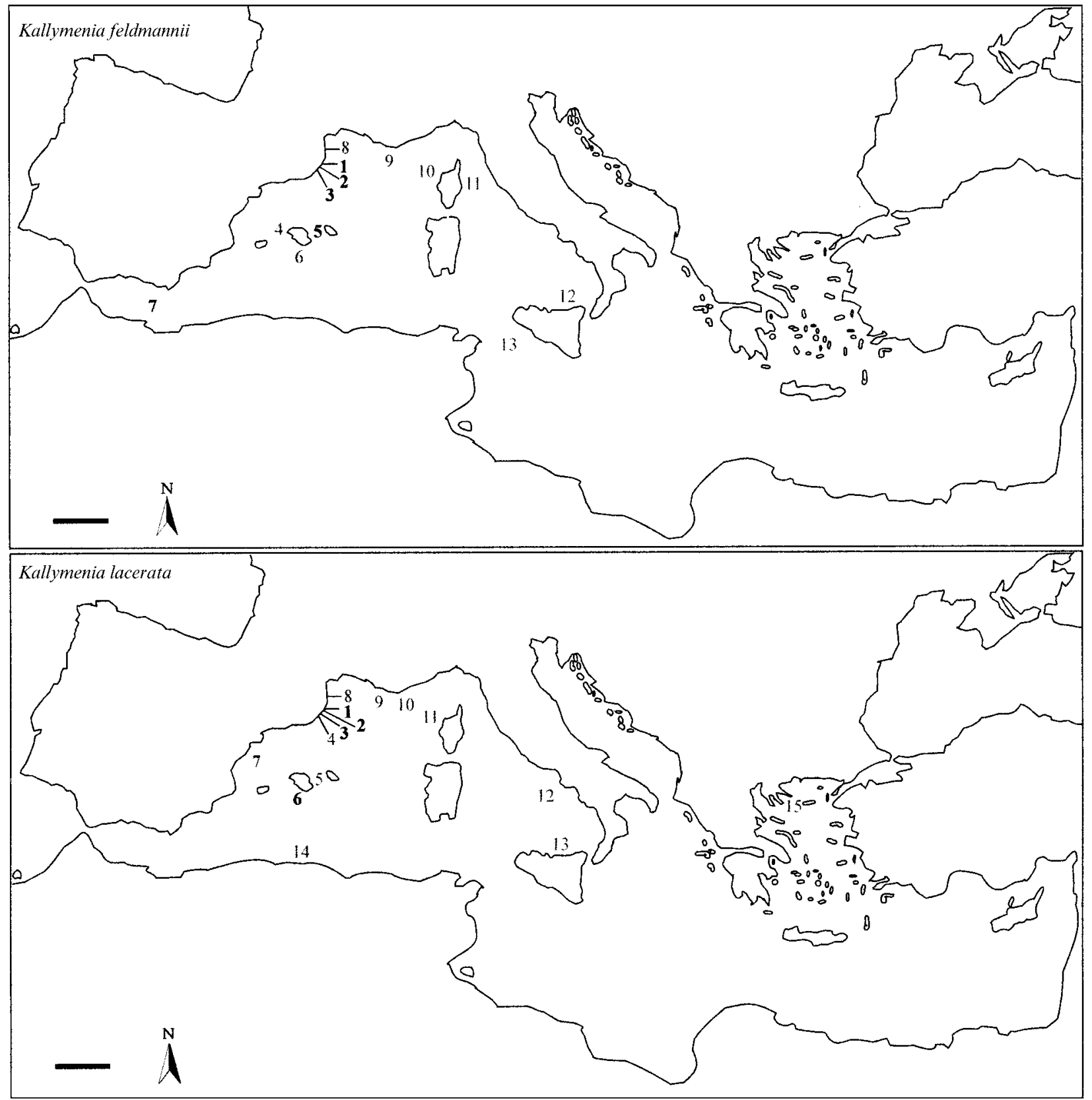

Fig. 1. Geographical distribution of Kallymenia feldmannii and K. lacerata grouped by localities. Numbers correspond to Table I. New localities are in bold. Bar $=200 \mathrm{~km}$. 
de la Marenda (Codomier 1968, Boudouresque 1970), in Provence (J. G. Agardh 1851-1863), at Marseilles (Huvé and Passelaigue 1970) and in Corsica (Verlaque et al. 1977, Coppejans 1979, 1982). In Italy it has been found at Naples (Feoli and Bressan 1972), in Sardinia (Brambati et al. 1980), in Sicily and in the Strait of Messina (Mazza 1904, Codomier and Giaccone 1972, Giaccone 1972, Furnari and Scammacca 1973, Giaccone and Rizzi-Longo 1976, Furnari et al. 1977, Cormaci and Furnari 1979, Battiato et al. 1980, Giaccone et al. 1985, Marino et al. 1998). Finally, it is also known from the Strait of Sicily (Giaccone et al. 1972, 1973, Giaccone and Sortino 1974, Cinelli et al. 1976).

In this work we report on some new records from the northeast coast of Spain, the Minorca Channel and the Columbrets Islands (Table I, Fig. 2).

Habitat: Like the other species of the genus, Kallymenia patens lives in the coralligen. It is common in communities dominated by Rhodymenia ardissonei J. Feldmann, with which it can be easily confused. It has also been found in other habitats, as on the rhi- zomes of Posidonia oceanica (Linné) Delile (Codomier 1971).

Phenology: This species is present all year round, but has been always found sterile, except in June when it bore tetrasporangia. The female gametophyte was found on one occasion in the Island of Linosa, Italy (Cinelli et al. 1976) (Table II).

\section{Kallymenia requienii J. G. Agardh}

Rhodomenia requienii J. G. Agardh 1841: 12.

Kallymenia requienii J. G. Agardh 1842: 99; J. G. Agardh 1851-1863: 289; J. G. Agardh 1876: 220; Codomier 1971: 14, figs 8-14; Codomier 1972: fig. 30 (a-d), fig. 49 (b-d), figs 50-51, fig. 53, fig. 54 (e-f), fig. 55 (c-f); Ribera Siguán 1983: pl. 20 (a-b); Vergés 2000: 123-140; figs 29-38.

Euhymenia requienii Kützing 1843: 400; Kützing 1849: 743; Kützing 1867: pl. 81.

Kallymenia demissa J. G. Agardh 1892: 67; Preda 1908-1909: 342 [as Callymenia demissa].

Table II. Annual reproductive behavior of the Catalan species of the genus Kallymenia, according to bibliographic data and our own observations.

\begin{tabular}{|c|c|c|c|c|c|c|c|c|c|c|c|c|c|}
\hline & Jan & Feb & Mar & Apr & May & Jun & Jul & Aug & Sep & Oct & Nov & Dec & UD \\
\hline \multicolumn{14}{|l|}{ Kallymenia feldmannii } \\
\hline Sterile & & & & 4 & 14 & 7 & 2 & 7 & & & & & \\
\hline Male gametophyte & & & & 1 & & & & & & & & & \\
\hline Female gametophyte & & & & & & 1 & & 4 & 1 & & & & \\
\hline Tetrasporophyte & & & & & & 1 & & & 1 & & & & \\
\hline Male gametophyte and tetrasporophyte & & & & & & & & & & & & 1 & \\
\hline Female gametophyte and tetrasporophyte & & & & & & & & 2 & & & & & \\
\hline Phenological data unknown & & & 1 & & 2 & & 1 & 3 & 2 & & & & 12 \\
\hline \multicolumn{14}{|l|}{ Kallymenia lacerata } \\
\hline Sterile & & & & 2 & 13 & 6 & 2 & 8 & 1 & & & & 1 \\
\hline Male gametophyte & & & & & & & 1 & & & & & & \\
\hline Female gametophyte & & & & & & & & & 1 & 2 & & 1 & \\
\hline Male and female gametophyte & & & & & & & & 2 & & & & & \\
\hline Tetrasporophyte & & & & & & & & 1 & 1 & & & & \\
\hline Phenological data unknown & & & & & 1 & & & 2 & 1 & 2 & & & 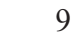 \\
\hline \multicolumn{14}{|l|}{ Kallymenia patens } \\
\hline Sterile & & & & & 1 & 9 & 6 & 2 & 1 & & & 1 & \\
\hline Female gametophyte & & & & & & & & & & & & & \\
\hline Tetrasporophyte & & & & & & 1 & & & & & & & \\
\hline Phenological data unknown & 2 & & & 1 & 1 & 1 & 4 & 3 & 3 & 2 & 2 & & 21 \\
\hline \multicolumn{14}{|l|}{ Kallymenia requienii } \\
\hline Sterile & & 1 & 1 & 6 & 16 & 22 & 12 & 2 & 2 & & & 1 & 2 \\
\hline Male gametophyte & & & & 2 & 1 & & & & & & & & \\
\hline Female gametophyte & & & 3 & 4 & 4 & 3 & & 2 & 2 & 1 & & & \\
\hline Tetrasporophyte & & & & 2 & 1 & 2 & & & 1 & & & 1 & \\
\hline Female gametophyte and tetrasporophyte & & & & & & & & & & & & & \\
\hline Phenological data unknown & 1 & 2 & 1 & 3 & 5 & 9 & 7 & 4 & 9 & 10 & & & 32 \\
\hline
\end{tabular}

UD: undated specimens 
Callymenia tenuifolia (Rodríguez Femenías manuscript) J. Feldmann 1935: 368; J. Feldmann 1939: 327 , figs $24-25$.

Kallymenia rigida J. Feldmann 1942: 13, fig. 4.

Geographical distribution: Kallymenia requienii has been found on many occasions in the western Mediterranean Sea, where it is quite common, and once in the eastern Mediterranean Sea, in the Bay of Akkuyu, Mersin, Turkey (Cirik 1991) (Table I, Fig. 2). In Spain it is known from the northeastern coast (Ballesteros i Sagarra and Romero Martinengo 1982, Ballesteros i Sagarra 1983, 1984, Ballesteros et al. 1984, Verlaque 1990), from the Balearic Islands (Seoane-
Camba 1969, Codomier 1971, Ballesteros 1992b, 1993, 1994), from the Columbrets Islands (Boisset López 1987, Boisset and García-Carrascosa 1987), from the coast of Alicante (Boisset López 1987) and from the Alboran Sea (Giaccone 1972). In France, it has been found at Banyuls and in Cerbère de la Marenda (Feldmann 1935, 1939, Codomier 1968, Boudouresque 1970, Coppejans 1976-1977), in the region of Marseille (J. G. Agardh 1842, Mouret 1911, Huvé and Passelaigue 1970, Codomier 1971), in the National Park of Port-Cros (Boudouresque 1970, Belsher et al. 1976, Coppejans 1976-1977, Augier and Boudouresque 1978), at Villefranche sur Mer, Alpes-Maritimes (Feldmann 1942), at different sites
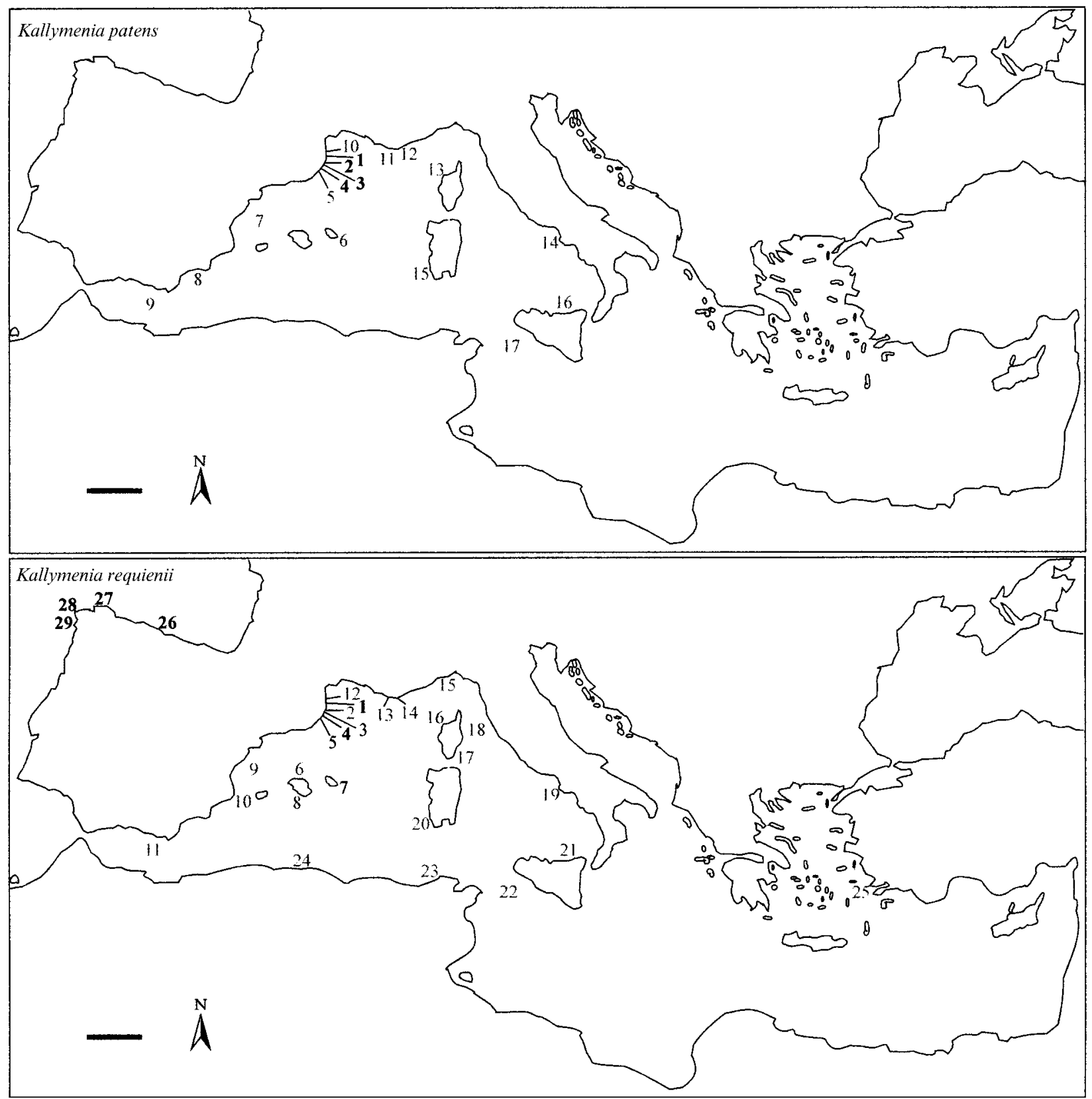

Fig. 2. Geographical distribution of of Kallymenia patens and K. requienii grouped by localities. Numbers correspond to Table I. New localities are in bold. Bar $=200 \mathrm{~km}$. 
in Corsica (Molinier 1960, Coppejans 1979, Verlaque 1987) and in the Lavezzi Islands (Boudouresque 1980, Frick et al. 1986). In Italy it is known from the Island of Montecristo, Tuscany (Papi et al. 1992), from Naples (Cinelli and Codomier 1974), from Sardinia (Brambati et al. 1980), from different points in Sicily and from the Strait of Messina (Lagenbach 1873, Ardissone 1883, Mazza 1904, Spinelli 1905, Giaccone 1969, 1972, Codomier and Giaccone 1972, Furnari and Scammacca 1973, Furnari et al. 1977, Cormaci and Furnari 1979, Battiato et al. 1980, Cormaci et al. 1985, Giaccone et al. 1985) and from the channel of Sicily (Codomier and Giaccone 1972, Giaccone et al. 1972, 1973, Giaccone and Sortino 1974, Cinelli et al. 1976). In Algeria it has been found at Alger (Montagne 1846, Debray 1897) and at Borj-elBahri (Feldmann 1942). Finally, in Tunisia it is known from Tabarka (Boudouresque 1970). Kallymenia requienii has been also recorded from Kabaena, Indonesia, as Kallymenia requienii var. indica (Webervan Bosse 1928), but due to the great distance of this site from the Mediterranean Sea and to the incomplete description of the specimen, we suspect it was a misidentification.

We have found this species in some new places on the northeastern coast of Spain, in the Balearic Islands and in the Columbrets Islands. We have also located this species for the first time on the Atlantic coasts, in specimens from the herbarium of the University of Santiago de Compostela. These specimens came from Santander, A Coruña, Pontevedra and Lugo (Table I, Fig. 2).

Habitat: The Mediterranean individuals of Kallymenia requienii grow in the coralligen or, less commonly, in maerl. The maximum depth where they have been found is $95 \mathrm{~m}$, in Minorca, where it was found in the 19th century by J. J. Rodríguez y Femenías (Seoane-Camba 1969). Associated species in its habitat are the same as for $K$. feldmannii and $K$. lacerata. The Atlantic specimens are usually found in the low sublittoral level, attached to rocky bottoms.

Phenology: This species has been collected all year round, except in November, and it is fertile from spring to autumn, bearing female reproductive structures throughout this period and tetraspores in spring. Male reproductive structures have only been found in April and May (Table II).

\section{Discussion}

The genus Kallymenia from Catalonia is represented only by four species (K. feldmannii, $K$. lacerata, $K$. patens and $K$. requienii). Kallymenia feldmannii and $K$. patens are found exclusively in the western Mediterranean Sea; K. lacerata is known from the western Mediterranean Sea and from Greece; and $K$. requienii is the most widespread species, being present in the western Mediterranean Sea, in Turkey, and also on the Atlantic coast of the Iberian Peninsula. After examination of the herbaria from the University of Las Palmas de Gran Canaria (BCM) and from the University of la Laguna (TFC), there is no record of these species in the Canary Islands. The individuals of $K$. feldmannii (BCM 1898) and K. requienii (BCM 634, BCM 1000, BCM 1892 and BCM 1893) in these herbaria were misidentified and in our opinion they belong to other species of the genus from the Macaronesian area or to other genera. The other specimens of the genus Kallymenia in this herbaria were also examined but did not belong to any of the four species studied.

The genus Kallymenia is sciophilous. In the Mediterranean Sea it is common in the coralligen, but it may also be present in maerl, usually at depths of more than $30 \mathrm{~m}$. Sometimes it can be found at shallower depths, albeit usually in dark places (entrances to caves, etc.). On the Atlantic coast, $K$. requienii is found in low sublittoral zones, attached to rocky bottoms.

Kallymenia feldmannii and $K$. lacerata seem to be annual because they have never been collected in winter (Table II). The culture of carpospores and tetraspores of K. feldmannii (Codomier 1972) shows that this species is able to develop incrusting discoid structures that can survive for long periods of time (some months in our own cultures) and in this way ensure survival in winter. The development of erect vegetative structures is stimulated from the discs with increasing light and temperature. On the other hand, $K$. patens and $K$. requienii seem also to be able to develop incrusting discs from carpospores (i. e. culture of carpospores of K. requienii, Codomier 1972), but erect fronds have been found all year round. Young individuals are present in spring and are small and pink. From spring to autumn they grow and accumulate floridean starch in the intermediate layers of cortical cells (never in the first layer or the outer one), with the plant showing whitish spots on the blade surface. Older individuals are totally whitish when viewed macroscopically (Figs 3-5, 11-12). The blade is destroyed during the autumn storms and, during winter, only the basal part of the frond is present in nature. This strategy is another way to ensure survival in winter. In spring, some new blades, pink-colored, without floridean starch and well distinguishable from the old ones, are developed over the old whitish and well epiphytised ones (Figs 5, 12).

The accumulation of floridean starch is very apparent in light microscope surface view of old individuals, as the margin, occupied by younger cells (growth is marginal), is optically less dense than the inner part of the blade, where older cells have accumulated the floridean starch (Figs 6-7; 13-14). This is also apparent in cross sections, because the inner cortical cells of young individuals 

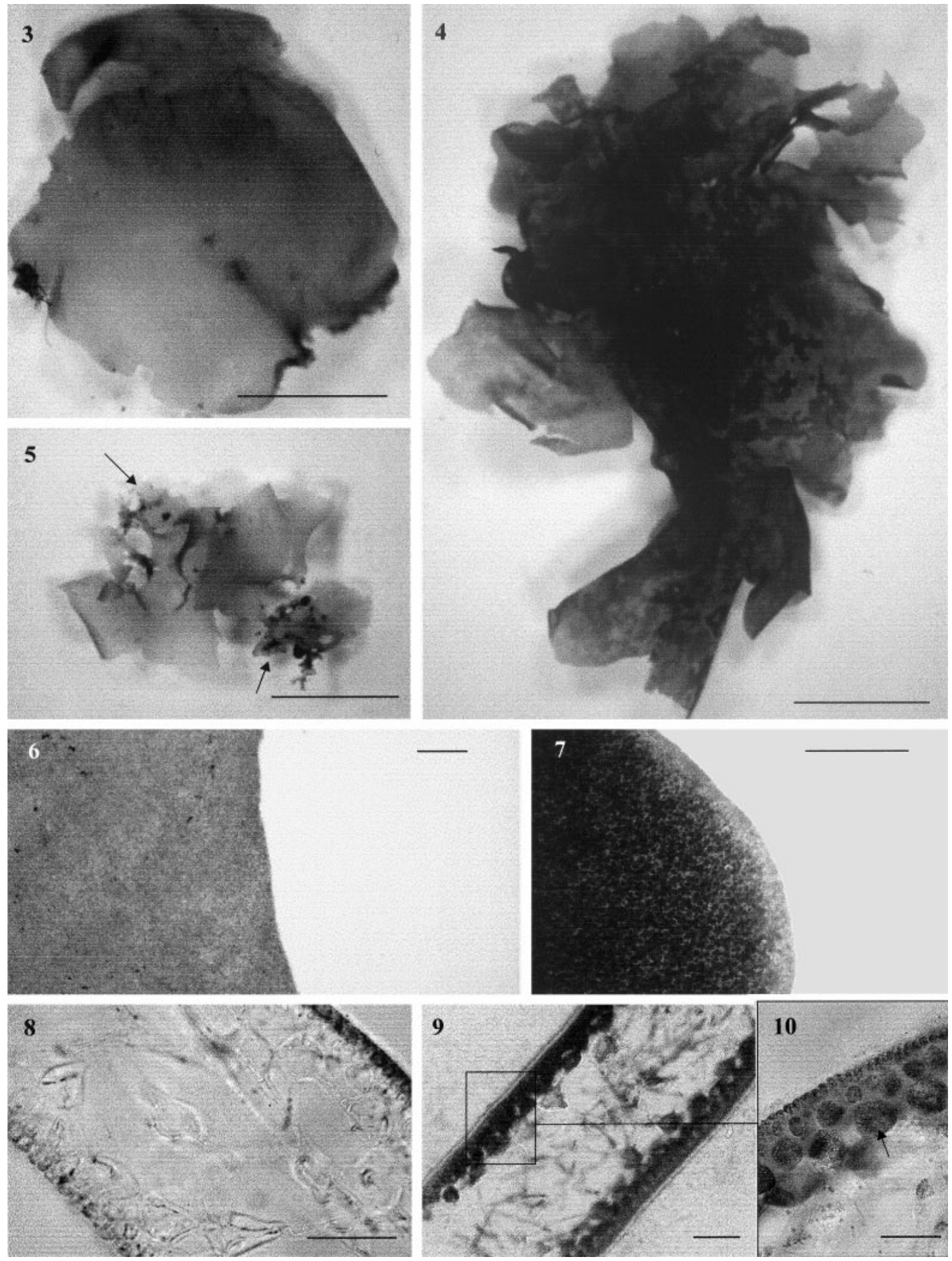

Figs 3-10. Kallymenia requienii.

Fig. 3. Young individual. Fig. 4. Individual showing whitish spots on the blade surface. Fig. 5. Individual more than one year old showing new blades developed over the old whitish ones (arrows). Fig. 6. Margin of the thallus of a young individual in surface view. Fig. 7. Margin of the thallus of an old individual in surface view. The accumulation of floridean starch in the adult cells makes the inner part of the blade optically dense. Fig. 8. Transverse section of the thallus of a young individual. Fig. 9. Transverse section of the thallus of an old individual. Fig. 10. Enlargment of part of Fig. 9 showing floridean starch in the intermediate cortical cells (arrows). Bars: Figs 3-5 = $1 \mathrm{~cm}$; Figs 6-7, $9=100 \mu \mathrm{m}$; Figs $8,10=50 \mu \mathrm{m}$. 

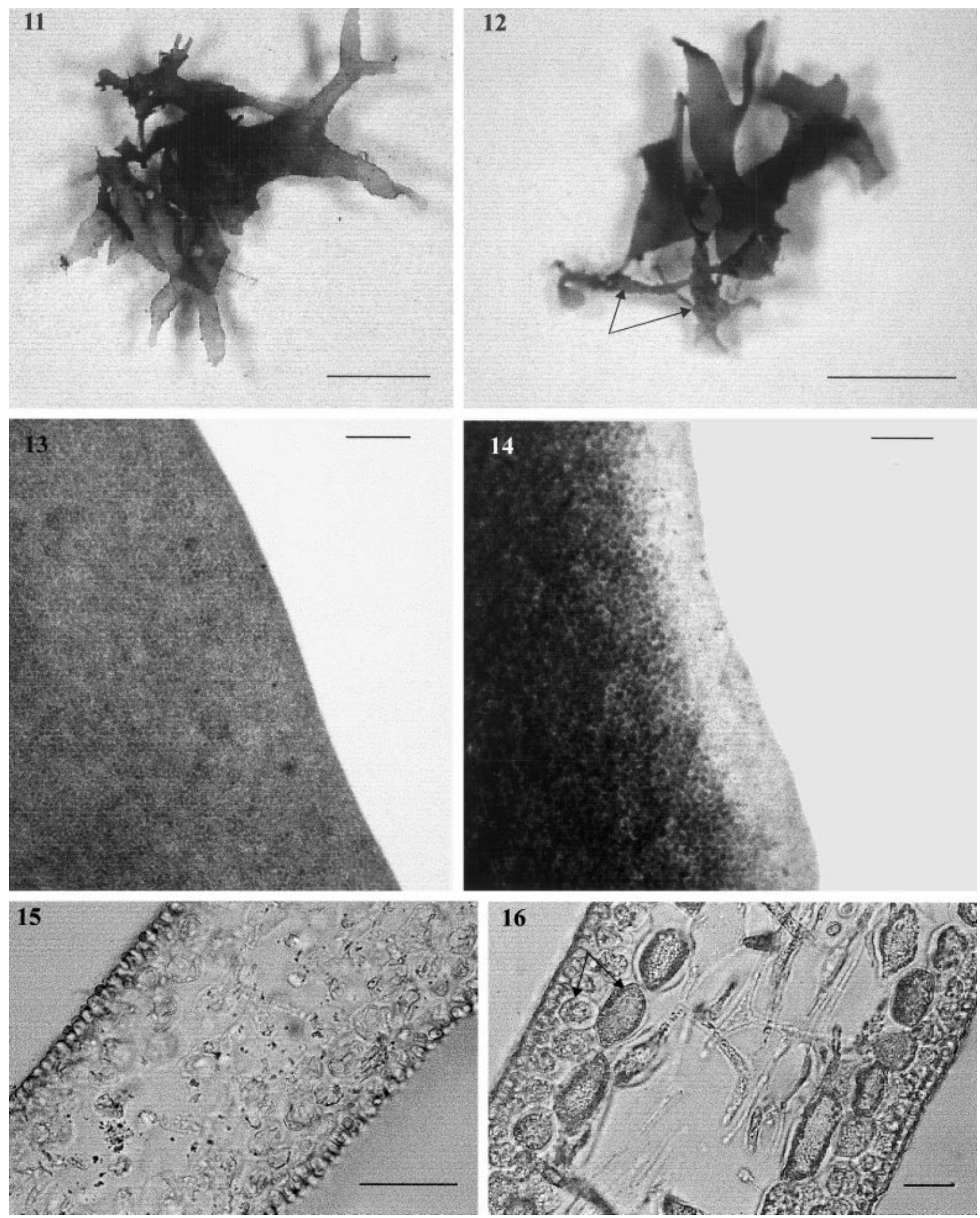

Figs 11-16. Kallymenia patens.

Fig. 11. Young individual. Fig. 12. Individual more than one year old showing new blades developed over the old whitish ones (arrows). Fig. 13. Margin of the thallus of a young individual in surface view. Fig. 14. Margin of the thallus of an old individual in surface view. The accumulation of floridean starch in the adult cells makes the inner part of the blade optically dense. Fig. 15. Transverse section of the thallus of a young individual. Figs. 16. Transverse section of the thallus of an old individual showing floridean starch in the intermediate cortical cells (arrows). Bars: Figs $11-12=1 \mathrm{~cm}$; Figs $13-14=100 \mu \mathrm{m}$; Fig. $15=50 \mu \mathrm{m}$; Fig. $16=25 \mu \mathrm{m}$. 
are hyaline, whereas in the old individuals there is a dark and optically dense intermediate cortical layer (Figs 8-10, 15-16). We think that the accumulation of floridean starch is not related to the irradiation of the site as was suggested by Codomier (1972), but is related to the age of the plant as we have shown here.

\section{References}

Agardh, J. G. 1841. In historiam algarum symbolae. Linnaea 15: 1-50, 443-457.

Agardh, J. G. 1842. Algae maris Mediterranei et Adriatici, observationes in diagnosin specierum et dispositionem generum. Parisiis [Paris]. pp. X +164.

Agardh, J. G. 1851-1863. Species genera et ordines algarum, seu descriptiones succinctae specierum, generum et ordinum, quibus constituitur. Vol. 2: Florideae. Lundae [Lund]. pp. XII + 1291. [Part 1, pp. [I]-XII + [1]-336 + 337-351 (Addenda and Index) (1851); part 2, fasc. 1, pp. 337-504 (1851); part 2, fasc. 2, pp. 507-700+ 701-720 (Addenda and Index) (1852); part 3, fasc. 1, pp. 701-786 (1852); part 3, fasc. 2, pp. 787-1291 (1139-1158 omitted) (1863)].

Agardh, J. G. 1876. Species genera et ordines algarum. Vol. 3: de Florideis curae posteriores. Part 1. Epicrisis systematis Floridearum. Lipsiae [Leipzig]. VII+724 pp.

Agardh, J. G. 1892. Analecta Algologica. Lunds Universitets Ars-Skrift, Andra Afdelningen, Kongl. Fysiografiska Sällskapets i Lund Handlingar 28 (6). 182 pp., III pls.

Ardissone, F. 1883. Phycologia mediterranea. Part 1. Floridee. Mem. Soc. Criptog. Ital. Varese 1: X +516 pp.

Athanasiadis, A. 1987. A survey of the seaweeds of the Aegean sea with taxonomic studies on species of the tribe Antithamnieae (Rhodophyta). Akad. Filos. Doktorsexamen Mar. Bot. Univ. Gothenborg. Sweden. pp. 174.

Augier, H. and C. F. Boudouresque. 1978. Végétation marine de l'île de Port-Cros (Parc National). XVI: Contribution à l'étude de l'épiflore du détritique côtier. Trav. Sci. Parc. Natl. Port-Cros 4: 101-125.

Ballesteros, E. 1992a. Contribució al coneixement algològic de la Mediterrània espanyola. IX. Espècies interessants de les Illes Balears. Fol. Bot. Misc. 8: 77-102.

Ballesteros, E. 1992b. Els fons rocosos profunds amb $O s-$ mundaria volubilis (Linné) R. E. Norris a les Balears. Boll. Soc. Hist. Nat. Balears 35: 33-50.

Ballesteros, E. 1993. Algues bentòniques and fanerògames marines. In: (J. A. Alcover, E. Ballesteros and J. J. Fornós, eds) Història Natural de l'Arxipèlag de Cabrera. Mon. Soc. Hist. Nat. Balears 2. pp. 503-530.

Ballesteros, E. 1994. The deep-water Peyssonnelia beds from the Balearic Islands (Western Mediterranean). Mar. Ecol. 15: 233-253.

Ballesteros, E., M. Pérez Vallmitjana and M. Zabala. 1984. Aproximación al conocimiento de las comunidades algales de la zona infralitoral superior en la costa catalana. Collect. Bot. (Barc.) 15: 69-100.

Ballesteros, E., S. Pinedo and C. Rodríguez-Prieto. 1997. Contribució al coneixement algològic de la Mediterrània espanyola. X. Acta Bot. Barc. 44: 29-37.

\section{Acknowledgements}

This work was funded by the Project PB95-0385C06-06 (DGES). We thank Kike Ballesteros and Natàlia Sant for the valuable material provided and Toni Murray (Unisub, L'Estartit) for helping us to find the best algal fields in the Medes Islands.

Accepted 23 March 2001.

Ballesteros i Sagarra, E. 1980. Aproximació a la sistemàtica and autoecologia de les algues bentòniques and litorals de Tossa de Mar (Costa Brava). Tesi de Llicenciatura. Univ. Barcelona. pp. 280.

Ballesteros i Sagarra, E. 1983. Contribució al coneixement algològic de la Mediterrània espanyola III. Addicions a la flora de Tossa de Mar (Girona). Collect. Bot. (Barc.) 14: $43-53$.

Ballesteros i Sagarra, E. 1984. Els vegetals and la zonació litoral: espècies, comunitats and factors que influeixen en la seva distribució. Institut d'Estudis Catalans. Ph. Dr. Thesis. Univ. Barcelona. pp. 587.

Ballesteros i Sagarra, E. and J. Romero Martinengo. 1982. Catálogo de las algas bentónicas (con exclusión de las diatomeas) de la costa catalana. Collect. Bot. (Barc.) 13 (2): 723-765.

Battiato, A., M. Cormaci and G. Furnari. 1980. Alghe marine della costa Iblea. Atti III Convegno Siciliano di Ecologia. Iblei: La Natura e l'uomo. Noto: 1-38.

Belsher, T., H. Augier, C. F. Boudouresque and E. Coppejans. 1976. Inventaire des algues marines benthiques de la rade et des îles d'Hyères (Méditerranée, France). Trav. Sci. Parc. Natl. Port-Cros 2: 39-89.

Boisset, F. and A. M. García Carrascosa. 1987. El fitobentos de las islas Columbretes: flora y comunidades vegetales. In: (L. A. Alonso Mantilla, J. L. Carretero and A. M. García Carretero, eds) Islas Columbretes. Contribución al estudio de sus comunidades vegetales. Monografies 5. Generalitat Valenciana. pp. 269-297, 2 pls.

Boisset López, F. 1987. Estudio del fitobentos esciáfilo infralitoral de sustratos duros, en el litoral valenciano (España): flora y vegetación. Ph. Dr. Thesis. Univ. Valencia. pp. 387, 71 figs.

Boudouresque, C. F. 1970. Recherches de bionomie analytique, structurale et expérimentale sur les peuplements benthiques sciaphiles de Méditerranée occidentale (fraction algale). Thèse. Univ. Aix-Marseille II. pp. 624, 152 figs.

Boudouresque, C. F. 1980. Compte-Rendu de la Mission Rara-Avis sur la Façade Maritime du Parc Naturel Régional de Corse. Phytocénoses benthiques. Fac. Sci. Luminy, Marseille. pp. 76.

Brambati, A., E. Ghirardelli, G. Giaccone, G. Orel and E. Vio. 1980. Bionomia del canale di San Pietro (Sardegna): ricerche sedimentologiche, idrologiche e relievo aerofotogrammetrico in funzione della tipologia e della distribuzione delle comunità bentoniche. Nova Thalassia 4: 135-171, 6 figs. 
Cinelli, F. and L. Codomier. 1974. Note floristique et repartition de Rhodophycées rares (Kallymeniacées et Sebdeniacées) de la Méditerranée occidentale. G. Bot. Ital. 108: 13-18, 1 fig.

Cinelli, F., D. Drago, G. Furnari, G. Giaconne, B. Scammacca, A. Solazzi, M. Sortino and C. Tolomio. 1976. Flora marina dell'isola di Linosa (arcipelago delle Pelagie). Mem. Bio. Mar. Oceanogr., n.s. 6 (5): 141-172.

Cirik, S. 1991. À propos de la végétation marine de la baie d'Akkuyu (Mersin, Turquie). Flora Mediterranea 1: 205-212.

Codomier, L. 1968. Recherches sur les Kallymenia (Cryptonémiales) et sur quelques autres Rhodophycées foliacées de la Méditerranée. Thèse Doct. 3e Cycle. Univ. Paris. pp. 288, 57 figs.

Codomier, L. 1971. Recherches sur les Kallymenia (Cryptonémiales, Kallymeniacées). I. Les espéces Méditerranéennes. Vie Milieu 22, fasc. 1, sér. A: 1-54.

Codomier, L. 1972. Recherches sur la reproduction, le cycle de vie et l'ontogenèse des Cryptonémiales et des Gigartinales méditerranéennes à thalle foliacé. Thèse Doct. État. Univ. Paris VI. 1-179 pp., 139 figs, 2 maps.

Codomier, L. and G. Giaccone. 1972. Sur quelques algues du Détroit de Messine et des environs de la Sicile. G. Bot. Ital. 106: 339-349.

Coppejans, E. 1976-1977. Bijdrage tot de studie van de wierpopulaties (Chlorophyceae, Phaeophyceae, Rhodophyceae) van het fotofiel infralittoraal in het Noordwestelijk Mediterranaan bekken. Ph. Dr. Wetenschappen Rijksuniversiteit Gent. Deel I. Tekst: and-xix + 296 pls. Deel II. Iconografie: 1-3, 1-243. Deel III. Tabellen: and-iii +339 tables.

Coppejans, E. 1979. Végétation marine de la Corse (Méditerranée). III. Documents pour la flore des algues. Bot. Mar. 22: 257-266.

Coppejans, E. 1982. L'épiflore des substrats meubles de l'étage circalittoral dans la Baie de Calvi (Corse, Mediterranée). I. Inventaire. Biol. Jb. Dodonaea 50: 231-242.

Cormaci, M. and G. Furnari. 1979. Flora algale marina della Sicilia orientale: "Rhodophyceae, Phaeophyceae e Chlorophyceae". Inform. Bot. Ital. 11: 221-250.

Cormaci, M., G. Furnari and B. Scammacca. 1978. Ricerche floristiche sulle alghe marine della Sicilia orientale. Terzo contributo. Boll. Accad. Gioenia Sci. Nat. 13: 27-44.

Cormaci, M., G. Furnari and B. Scammacca. 1985. Osservazioni sulle fitocenosi bentoniche del golfo di Augusta (Siracusa). Boll. Accad. Gioenia Sci. Nat. 18: 851-872.

Debray, F. 1897. Catalogue des algues du Maroc, de l'Algérie et de la Tunisie. Librairie A. Jourdan edit. Alger. 78 pp.

De Toni, G. B. 1905. Sylloge Algarum omnium hucusque Cognitarum. Vol. IV. Florideae. Sectio IV. Patavii [Padova]. pp. $1523-1973$.

Feldmann, J. 1935. Algae marinae mediterraneae novae. Bull. Soc. Hist. Nat. Afr. Nord 26: 362-369.

Feldmann, J. 1939. Les algues marines de la côte des Albères. IV. Rhodophycées (Bangiales à Cryptonémiales). Rev. Algol. 11: 247-330.

Feldmann, J. 1942. Les Kallymenia (Rhodophycées, Cryptonémiales) des côtes d'Algérie. Bull. Soc. Hist. Nat. Afr. Nord 33: 7-14.
Feoli, E. and G. Bressan. 1972. Affinita floristica dei tipi di vegetazione bentonica della Cala di Mitigliano (Massa Lubrense, Napoli). G. Bot. Ital. 106: 245-256.

Frick, H., C. F. Boudouresque, J. G. Harmelin, F. Laborel, J. Laborel, A. Meinesz, J. Vacelet and M. Verlaque. 1986. Le benthos littoral des îles Lavezzi, première contribution. Trav. Sci. Parc. Natl. Rég. Rés. Nat. Corse 7: $1-133$.

Furnari, G. and B. Scammacca. 1973. Ricerche floristiche sulle alghe marine della Sicilia orientale. Nuovo contributo (con 12 figure fuori testo). Boll. Accad. Gioenia Sci. Nat., ser. 4, 11: 1-21 + III pls.

Furnari, G., B. Scammacca, M. Cormaci and A. Battiato. 1977. Zonazione della vegetazione sommersa dell'isola Lachea (Catania). Atti IX Congr. Naz. S. I. B M., Ischia: $245-257$.

Giaccone, G. 1969. Raccolta di fitobenthos sulla banchina continentale italiana. G. Bot. Ital. 103: 485-514.

Giaccone, G. 1972. Struttura, ecologia e corologia dei popolamenti a Laminarie dello stretto di Messina e del Mare di Alboran. Mem. Biol. Mar. Ocean. 2: 37-59.

Giaccone, G. and V. Di Martino. 1996. Flora, vegetazione marina e stato dell'ambiente nell'area iblea. Boll. Acc. Gioenia Sci. Nat. 29: 359-391.

Giaccone, G. and L. Rizzi-Longo. 1976. Revisione della flora dello stretto di Messina. (Note storiche, bionomiche, corologiche). Mem. Biol. Mar. Oceanogr., n.s. 6: 69-123.

Giaccone, G. and M. Sortino. 1974. Zonazione della vegetazione marina delle isole Egadi (Canale di Sicilia). Lav. Ist. Bot. Giard. Col. Palermo 25: 166-183.

Giaccone, G., B. Scammacca, F. Cinelli, G. Sartoni and G. Furnari. 1972. Studio preliminare sulla tipologia della vegetazione sommersa del Canale di Sicilia e isole vicine. G. Bot. Ital. 106: 211-229.

Giaccone, G., M. Sortino, A. Solazzi and C. Tolomio. 1973. Tipologia e distribuzione estiva della vegetazione sommersa dell'isola di Pantelleria. Lav. Ist. Bot. Giard. Col. Palermo 25: 103-119.

Giaccone, G., M. C. Alessi and M. Toccaceli. 1985. Flora e vegetazione marina dell'Isola di Ustica. Boll. Accad. Gioenia Sci. Nat. 18: 505-536.

Huvé, H. and F. Passelaigue. 1970. A propos de quelques Rhodophycées foliacées de la région de Marseille. Bull. Soc. Phycol. Fr. 15: 43-48, 2 pls.

Knoepffler, M., M. C. Noailles, C. F. Boudouresque and C. Abelard. 1990. Phytobenthos des Pyrénées-orientales: complement à l'inventaire. Presènce d'espèces non indigenes (Sargassum et Undaria). Bull. Soc. Zool. Fr. 115: 37-43.

Kützing, F. T . 1843. Phycologia generalis (oder Anatomie, Physiologie und Systemkunde der Tange). Leipzig. XXXII + 458 [459 = Verbesserungen $]$ pp. +80 pls.

Kützing, F. T. 1849. Species algarum. Lipsiae [Leipzig]. VI $+922 \mathrm{p}$.

Kützing, F. T. 1866. Tabulae phycologicae oder Abbildungen der Tange Nordhausen. Vol. 16. Nordhausen. [III +] 35 pp., 100 pls.

Kützing, F. T. 1867. Tabulae phycologicae oder Abbildungen der Tange Nordhausen. Vol. 17. Nordhausen. [III +] 30 pp., 100 pls. 
Lagenbach, G. 1873. Die Meeresalgen der Inseln Sizilien und Pantelleria. Weber ed. Berlin. i-vii +23 pp.

Marino G., V. Di Martino and G. Giaccone. 1998. La vegetazione marina nella Penisola Maddalena (Siracusa, Sicilia S-E). Boll. Acc. Gioenia Sci. Nat. 31 (354): 235-287.

Mazza, A. 1904. Un manipolo di alghe marine della Sicilia. Nuova Notarisia 15: 5-30, 49-75, 115-149.

Molinier, R. 1960. Etude des biocénoses marines du Cap Corse (France). Vegetatio 9: 121-312.

Montagne, C. 1846. Ordo I. Phyceae fries. In: Exploration Scientifique de l'Algérie pendant 1840-42, Sciences Naturelles, Botanique, 1, Cryptogamie. M. C. Durieu de Maisonneuve ed. Paris. pp. [1]-197, pls. 1-16.

Mouret, M. 1911. Liste des algues marines du Var. Ann. Soc. Hist. Nat. Toulon 11: 78-107.

Papi, I., G. Pardi, S. Lenzini, L. Benedetti Cecchi and F. Cinelli. 1992. Benthic marine flora in the Tuscan Archipelago. A first contribution: isles of Capraia, Elba, Formiche di Grosseto, Giglio, Scoglio d'Africa, Montecristo and Giannutri. G. Bot. Ital. 126: 549-593.

Parkinson, P. G. 1980. Halymenia Being a Critical Account of the Confused Nomenclature of Halymenia C.A. Agardh 1817, (Halymeniaceae, Cryptonemiales, Rhodophyta) with Reflections on the International Code of Botanical Nomenclature and Corrections to Certain Recent Work in Which It Has Been Disregarded. Pettifogging Press. Auckland. 20 pp.

Preda, A. 1908-1909. Flora italica cryptogama. Pars II: Algae. Florideae. Vol. I. Fasc. 2. Stabilimento typografico Capelli, Rocca S. Casciano. 462 pp., 130 figs.

Ribera Siguán, M. A. 1983. Estudio de la flora bentónica marina de las Islas Baleares. Ph. Dr. Thesis. Univ. Barcelona. pp. 636.

Rodríguez-Prieto, C., C. F. Boudouresque and J. MarcotCoqueugniot. 1993. Nouvelles observations sur les algues marines du Parc Naturel Régional de Corse. Trav. Sci. Parc Natl. Rég. Rés. Nat. Corse 41: 53-61.

Rodríguez y Femenías, J. J. 1889. Algas de las Baleares. Anal. Soc. Esp. Hist. Nat. 18: 199-274.

Seoane-Camba, J. 1969. Algas bentónicas de Menorca en los herbarios Thuret-Bornet y Sauvageau del Muséum National d'Histoire Naturelle de Paris. Invest. Pesq. (Barc.) 33: 213-260.

Soto Moreno, J. 1992. Datos sobre la flora y corología algal del litoral de Murcia (SE de España). Anales Biol. 18: $61-64$.

Spinelli, V. 1905. Le alghe marina della Sicilia orientale. Atti. Accad. Gioenia. Sci. Nat. Catania, ser. 4 18: 1-55.

Vergés, A. 2000. Revisió del Génere Kallymenia (Kallymeniaceae, Rhodophyta) a la Costa Catalana. Treball de Recerca. Univ. Girona. pp. 207.

Verlaque, M. 1987. Contribution à l'étude du phytobenthos d'un écosystème photophile termophile en Méditerranée Occidentale. Étude structurale et dinamique du phytobenthos et analyse des relations Faune-Flore. Thèse. Univ. Aix-Marseille II. pp. 389, 96 pls.

Verlaque, M. 1990. Flore marine benthique de la région de Galéria. Trav. Sci. Parc. Natl. Rég. Rés. Nat. Corse 29: 77-88.

Verlaque, M., C. F. Boudouresque, A. Meinesz, G. Giraud and J. Marcot-Coqueugniot. 1977. Végétation marine de la Corse (Méditerranée). II. Documents pour la flore des algues. Vie Milieu 27, sér. A: 437-456.

Weber-van Bosse, A. 1928. Liste des Algues du Siboga. IV. Rhodophyceae. Troisième Partie. Gigartinales et Rhodymeniales et Tableau de la Distribution des Chlorophycées, Phaeophycées et Rhodophycées de l'Archipel Malaisien. Siboga Exped. Monogr. 59d. Leiden. pp. 393-533, figs 143-213; pls. XI-XVI. 